\title{
More than just an experiment? Politicians arguments behind introducing participatory budgeting in Budapest
}

\author{
Dániel Oross ${ }^{1} \mathbb{D} \cdot$ Gabriella Kiss $^{2}$
}

Accepted: 28 October 2021

(c) The Author(s) 2021

\begin{abstract}
As deliberative and participatory practices play a greater role in political decisionmaking of democratic political systems in many parts of the world, political parties must adapt to demands of an increasingly more cognitively mobilized citizenry. While there is a growing body of literature about the functioning of such procedures in different social and political contexts, little is known about politicians' reasons behind introducing them. Based on qualitative data collected among Hungarian politicians, this paper brings evidence to empirically assess why local politicians introduced Participatory Budgeting in Budapest, Hungary. Our findings suggest that politicians accept theoretical arguments for promoting citizens' participation, newly elected local politicians expect to increase their party's local embeddedness by creating new contact opportunities and emphasize that the introduction of Participatory Budgeting is a ground for experimentation. The article ends with a discussion about arguments that are put forth in the literature on European Participatory Budgeting but missing from the views of politicians, and concludes by highlighting the risks of institutionalizing Participatory Budgeting.
\end{abstract}

Keywords Democratic innovations · Participatory democracy $\cdot$ Participatory budgeting $\cdot$ Local democracy $\cdot$ Hungary

Dániel Oross

oross.daniel@tk.mta.hu

Gabriella Kiss

gabriella.kiss@uni-corvinus.hu

1 Centre for Social Sciences, Institute for Political Science, Tóth Kálmán utca 4, 1097 Budapest, Hungary

2 Institute of Business Economics, Corvinus University of Budapest, Fơvám tér 8., 1093 Budapest, Hungary 


\section{Introduction}

There is a growing body of literature on the spread (Dias 2020) and internal functioning of deliberative and participatory procedures (Bächtiger et al. 2018; Elstub and Escobar 2019; Caluwaerts-Reuchamps 2015; Fishkin and Luskin 2005). An increasing number of critiques challenge representative regimes, presenting deliberative and participatory practices that involve citizens in public affairs as an antidote to cure democratic malaise (Dryzek et al. 2019; Smith 2009; Geissel and Newton 2012; Geissel and Joass 2013). This article contributes to the literature on reconnecting deliberation and political parties (Johnson 2006, p. 49), and to the emerging body of literature on the attitudes of political leaders toward the involvement of citizens in political decision-making.

Earlier research has provided arguments for public participation in general (Caluwaerts and Reuchamps 2018; Fung 2007; Geissel-Joas 2013; Smith 2009) and there is an account of purposes and values associated with participatory governance (Elstub and Escobar 2019; Sintomer et al. 2016; Wampler 2012). However, in order to highlight why political leaders may or may not prefer sharing power with ordinary people, there is a need for shifting attention from citizens' and experts' attitudes on participatory decision-making toward the attitudes of political leaders. Analyzing the extent to which MPs actually endorse different variants of 'sortition', a recent article (Jacquet et al. 2020) found that most MPs do not support democratic reform. Instead, potential reform patterns would consist of a minority of politicians advocating a reform that enjoys enough support from civil society groups to be imposed on the political agenda. Macq and Jacquet (2020) suggested that political leaders had interest in the creation of the Permanenter Bürgerdialog (PBD), a unique deliberative institution set up by the German-speaking Community of Belgium for two main reasons: building of a territory's political identity and the salvation of representative democracy. Recent empirical evidence on politicians' support for deliberation (Gherghina et al. 2020) highlighted reasons such as education of the party members and stakeholders, increased efficacy of the policy-making process, enhanced legitimacy of party decisions and strategic advantages in the electoral competition. But do these arguments also hold true for participatory processes? Joining the scientific debate on politicians' motives to set up deliberative and participatory procedures, we aim to highlight reasons behind politicians' support for the emergence of Participatory Budgeting.

This article contributes to answering the question why local politicians introduced Participatory Budgeting in Budapest, Hungary, by empirically analyzing the arguments of Hungarian politicians for establishing Participatory Budgeting in Budapest via documentary analysis of public records, electoral programs of Hungarian mayors and qualitative data taken from 27 semi-structured interviews with Hungarian politicians between March and August 2020. Hungary is the appropriate setting to answer this question because its party system includes political parties with different degrees of institutionalization. In Hungary, participatory decision-making does not look back on a rich past. However, one of 
the most striking changes since the 2019 municipal elections is the appearance of Participatory Budgeting, a process that allows non-elected citizens to take part in prioritizing or allocating public funds (Sintomer et al. 2016, p. 20). As the first systematic analysis on the case under scrutiny, our results indicate that among politicians there is a widespread acceptance of what we call 'theoretical arguments for promoting citizens' participation (increasing trust of citizens in democracy; increasing legitimacy of decisions; enhancing knowledge and improving understanding and community building). Based on the argument for increasing local embeddedness by creating new contact opportunities, politicians expect that Participatory Budgeting can convince citizens that politicians are responsive to their demands. Additionally, politicians in Hungary emphasize the introduction of Participatory Budgeting as a means of experimentation and new terrain for newly elected local politicians.

The article is structured as follows. The first section offers a review of the literature on the relation between political leaders and participatory budgeting and on the reason why politicians support the process. The second presents the methodology and the data we analyzed. The following section presents the ongoing institutionalization of Participatory Budgeting in Budapest. Then, findings are presented in the fifth section Followed by a discussion about missing arguments and a conclusion.

\section{Why do politicians support external participatory tools?}

Literature on arguments for public participation in general has provided us with a set of arguments about the benefits of participatory decision-making (Laird 1993; Wilcox 1994; Habermas 1996; Király et al. 2016; Kiss 2014). These arguments are different on the basis of who benefits from the participatory process: the local community, the decision-makers or the whole society (Király et al. 2016). With regard to the whole society, the literature emphasized that through participation people's interests and perspectives can be changed during the process, and social learning can occur (Laird 1993; Habermas 1996). More specifically, participation can have an educative function: people can learn democracy through decision-making processes and increase their knowledge on the given topic (Talpin 2011; Kiss 2014). From the perspective of the decision-makers, the quality of the decisions can be enhanced as different stakeholder's knowledge and experience can be taken into account. Conflicts can be prevented or resolved with a well-organized participatory process (King et al. 1998), and commitment on decisions can increase. From the community point of view, participation has a community-building element as community members can connect to each other and become more motivated to acquire information and discuss these questions within the community (Király et al. 2016). Last but not least, people have a psychological need for defining their own living conditions (Ariely 2010; Iyengar 2010).

Connecting lessons drawn on participation theory and policy documents, Dean (2017) came up with four archetypal modes of public participation in policy decisions: (1) knowledge transfer; (2) collective decision-making; (3) choice and voice; and (4) arbitration and oversight. Empirical research about 
participatory governance foregrounded normative imperatives behind participation categorizing consumerist, technocratic and democratic rationales (Hickman 2006; Martin 2009). An in-depth account of purposes and values associated with participatory governance challenged that categorization and identified participation preferences of key actors along three categories: (1) participation as collective decision-making; (2) participation as knowledge transfer; and (3) participation as agonism and that different actors support different arguments (Dean 2019).

While there is a predominant attention to citizens' and experts' attitudes toward participatory decision-making, an important dimension is left aside: the attitudes of political leaders toward different participatory tools. There is some evidence on the expectations of political leaders toward public participation (Hendriks and Lees-Marshment 2019; Schiffino et al. 2019). According to Hendriks and Lees Marshment (2019), political leaders prefer informal channels to formal participatory instruments and the main reasons of political leaders to support public participation are related to collecting information, connecting with real people, checking the feasibility of new policies, and aiding policy implementation. Mostly consultation and co-governance initiatives are likely to find favor with local politicians (Mckenna 2012) and the main argument for using participatory devices is that they reinforce political leaders' role as the central decision-makers (Schiffino et al. 2019). Yet little attention is paid to the fact that the involvement of lay citizens in the decision-making process can potentially restrict the autonomy of political leaders (Macq and Jacquet 2020). In order to highlight why political leaders do or do not seem to prefer sharing power with ordinary people, more attention is necessary to the supportive and opposing arguments of politicians.

In our paper, we focus on a specific form of participatory decision-making: we selected Participatory Budgeting because of its flexibility as it has been imported into and adapted for very different places (Hernandez-Medina 2010; Patsias et al. 2013; Nez 2016; Kempa and Kozlowski 2020). Although scholarship has mainly focused on the particular political and social context where the Participatory Budgeting got established, reasons for which politicians would favor this approach were not yet explained by comparative studies. As for its benefits for politicians, it is important to note that Participatory Budgeting started in Porto Alegre to foster community participation in the making of public decisions (Abers 2000; Wampler 2012). One possible explanation for politicians' preference for this participatory tool is their parties' need for tighter connections with the electorate. Although organizational communication requires more resources and time than direct communication initiated by party leaders, its coverage can be wider. We assume that through its personal approach it enhances long-term bonds between voters and parties. We selected an influential case (Seawritght and Gerring 2008) from Central Eastern Europe where parties lack stable connections with local associations (Gherghina 2014, p. 40) to test if politicians support to PB stems mainly from local politicians' need for incentives to complement party leaders' communication with the electorate. 


\section{Research method}

In this exploratory research, we used a combination of document analysis and interviews to answer the research question why politicians decided to introduce Participatory Budgeting in Budapest. We analyzed manifestos of candidates who have explicitly mentioned Participatory Budgeting before or during the 2019 local electoral campaign, treating selected documents like a respondent or informant that provides the researcher with relevant information (O'Leary 2014). We conducted 27 semi-structured interviews with Hungarian politicians in Budapest between March and August 2020. In order to cover the three faces of party organization (Katz and Mair 1993, p. 594) and to understand how organizational communication through PB complements leaders' communication with the electorate, elected representatives of party in public office (e.g., presidents of each party, heads of the Parliamentary Groups, selected Members of the European Parliament), in the central office (e.g., operative director) and on the ground (Party leaders at local level, Mayors, local councillors in Budapest) were invited to take part in the research. In order to reveal parties' links to society, party experts were also invited.

In order to gain information about the topic, purposive sampling was required to focus on politicians with some experience (e.g., elected in municipalities where PB was introduced) with Participatory Budgeting. As left-wing parties are generally more active in initiating such processes, members in left-wing parties are overrepresented in our sample. The interview guide included 12 questions about party membership, representatives' activities, the meaning of participatory democracy, various decisions reached within the party, online activities and democratic innovations such as Participatory Budgeting. The average duration of the interview was $50 \mathrm{~min}$. The interviewees belong to 10 Hungarian parties (see Appendix 2).

Interviews were transcribed and analyzed using the NVivo software. To identify common themes (arguments) within the interviews, we used a data-driven thematic analysis, a method for identifying, analyzing and reporting patterns (themes) within data, because of its flexibility and advantage in highlighting similarities and differences across the data set (Braun and Clarke 2006, p. 97). The coding was inductive: we read all interviews and identified potential themes based on the literature. The procedures consisted of three phases. The researchers read independently all interviews, identified the main arguments and grouped the interviews according to them in phase one. During phase two an inter-coder reliability test was applied in which arguments provided earlier were compared and contrasted, including the interviews associated with those themes. In phase three, authors came up with a final list of arguments and interviews associated with them. 


\section{The story of participatory budgeting in Budapest}

Hungary is a representative democracy with some limited experience with direct democracy (Pállinger 2016). There are no provisions in the legislation that explicitly refer to the concept of participatory budgeting and local participatory budgeting is a relatively new phenomenon. Compared to the five kinds of actors that have contributed to the spread of Participatory Budgeting in Europe (Sintomer et al. 2016, pp. 39, 40), it was introduced in Hungary by the green movement and supported mostly by newly elected local MPs of different NGOs (see Table 1).

Inspired by the message 'Another World is Possible', Hungarian green activists organized a series of events that resulted in founding the 'Green Party Politics Can be Different' movement in 2009. In 2010 the party entered the Parliament, but the Orban regime's shift toward an illiberal direction (Bozóki and Hegedús 2018; Buzogány 2017) had a fairly negative effect on democratic innovation and few priorities of green politics were implemented at a national level.

The institution of 'community budget' was introduced in Hungary by the local government of the XIX. district of Budapest (Kispest), which was fulfilling an electoral pledge of the incumbent socialist mayor inspired by the coalition partner green party. In 2016, the municipality enabled citizens to choose from 16 development projects while in 2018, items to be put to the ballot were selected from locals' suggestions refuting earlier critics who claimed that the process reduced citizens' capacity. The mayor's manifesto for the 2019 local elections promised to continue the process in each budget year and to allocate budget resources based on the votes of the neighborhoods. In 2019, the XXII. district of Budapest led by the mayor of Fidesz-KDNP also decided to introduce Participatory Budgeting.

Those early birds of Participatory Budgeting inspired the candidates of the opposition running for the position of the mayor of Budapest during the 2019 local elections (Annex 1 highlights the profile and relative 'size' of Hungarian parties). Following two rounds of primaries, the winner, a former Green Party MP, has successfully forged unity among the fractured opposition parties and gained their

Table 1 The main actors of promoting Participatory Budgeting in Budapest

\begin{tabular}{ll}
\hline Comparative angles & Budapest \\
\hline $\begin{array}{l}\text { 1. Left wing political parties } \\
\text { 2. Social movements }\end{array}$ & $\begin{array}{c}\text { Little interest in introducing PB (one local organization of MSZP) } \\
\text { The green movement took part in Social Forums and they have put the } \\
\text { topic on the agenda of Hungarian politics }\end{array}$ \\
3. Civil society organizations & $\begin{array}{r}\text { In several municipalities members of different NGOs run independently } \\
\text { during the municipal elections in 2019. After being elected as local } \\
\text { representatives they became promoters of PB }\end{array}$ \\
$\begin{array}{l}\text { International organizations had little impact on the process in Hungary } \\
\text { 5. Participation professionals }\end{array}$ & $\begin{array}{c}\text { Participation professionals benefited from different programs of the } \\
\text { European Union and those professionals play an ever increasingly } \\
\text { important role in providing knowledge and analytical skills to local } \\
\text { government employees recently }\end{array}$ \\
\hline
\end{tabular}

Source: Sintomer et al. (2016, pp. 39, 40) and own estimation

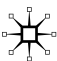


support for his program. His manifesto promised that in case of major investments and developments, he would use the tools of community planning and experiment with Participatory Budgeting that has successfully been introduced in several European cities (for example, Paris, Lisbon) and in the XIX. district of Budapest. The candidate of the liberal party Momentum (who later became the Deputy Mayor of Budapest in charge of smart city projects) promised in his manifesto to involve the widest possible range of society in urban decision-making as much as possible and named community budgets as means to facilitate that promise. Opposition parties managed to turn municipal elections into 'a referendum against the government' and gained a majority both in the General Assembly of Budapest and in the majority of the twenty-three districts of the Hungarian capital city. Following the 2019 municipal elections in addition to the Budapest Municipality, several local governments of Budapest (1st, 3rd, 8th, and 9th districts) separated a small sum (about 1\%) for local Participatory Budgeting as part of their annual budget of 2020 ( see Fig. 1).

In sum, Participatory Budgeting (PB) has no legal background in Hungarian legislation and its implementation is in a preliminary phase in most districts of Budapest. At this stage of our research, it is too early to write about details of the PB processes (how the selection committees have been created, how promotional and educational campaigns have been organized etc.) as it has been formulating annually. In particular parts of the city, different models are initiated and the processes are in various phases, which is the reason for the focus of this research. What can be said in general is that the PB is created through decisions as part of the annual budget and the implementation of the process is controlled by the Mayor or a designated Deputy Mayor of the municipalities with different levels of commitment to seize its recommendations. Budapest has a dual self-government system, there are different models of participatory budgeting in the districts and in the City Council of Budapest. PB in Budapest mostly resembles the participatory modernization model

\section{Overview of Participatory Budgets in Budapest}

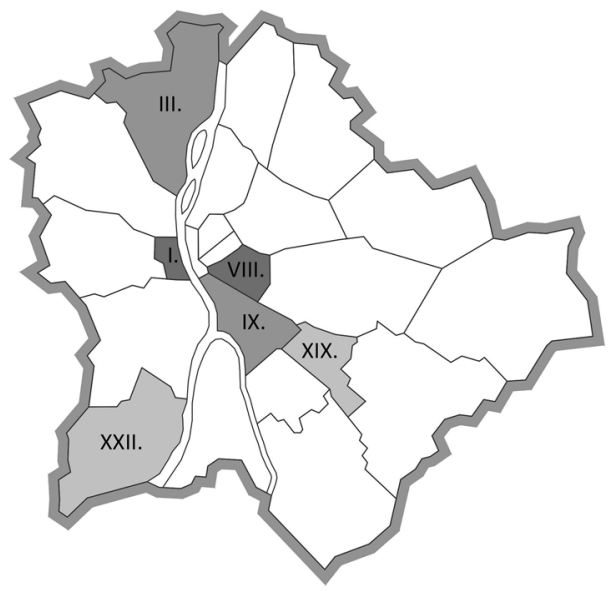

\begin{tabular}{c|c|c|} 
TERRITORY & YEAR & $\begin{array}{c}\text { AMOUNT OF PB } \\
\text { (EUR) }\end{array}$ \\
\hline XIX. DISTRICT & 2016 & 117000 \\
\hline XXII. DISTRICT & 2019 & 833000 \\
\hline III. DISTRICT & 2020 & 139000 \\
\hline IX. DISTRICT & 2020 & 14000 \\
\hline BUDAPEST CITY COUNCIL & 2020 & 2747000 \\
\hline I. DISTRICT & FORTHCOMING & NO DATA \\
\hline VIII. DISTRICT & FORTHCOMING & NO DATA \\
\hline
\end{tabular}

Fig. 1 Overview of Participatory Budgets in Budapest 
of Sintomer et al. typology (2016, p. 47) that offers consultation on public finances for citizens and gives local people a say in planning a small percentage of the total budget.

\section{The main arguments for participatory budgeting}

After getting to know the conditions of PB in Budapest and exploring the most important actors, we present the results of our analysis in this chapter. From the interviews with politicians, the arguments that led decision-makers to introduce PB are clearly outlined. In this findings section, we explore the arguments that political leaders associated with the creation of PB at the local level.

These arguments emerged from the analysis of the transcribed interviews using data-driven thematic analysis (see Sect. 3). The interviews included two questions about the meaning of (1) participatory democracy and (2) Participatory Budgeting. After coding and analyzing the answers of interviewees, we identified three main arguments.

The three main thematic arguments that were emphasized by the interviewed politicians were (1) PB promotes public participation, (2) PB is an effective communication tool that connects politicians with citizens, and (3) PB serves as a social experiment. In the following, Table 2 summarizes the key features of the arguments and they will be presented in detail in the next section.

\section{Promoting public participation}

As the realization of participatory democracy in Hungary is a new field, politicians give credit to theoretical arguments for promoting public participation. The argument for public participation in general was mentioned by the interviewees on the one hand when talking about mistrust in political decisions at the local level and on the other hand in building trust in democracy and democratic institutions. In support of the latter case, empowerment makes democratic institutions stronger and builds trust in citizens among them. Within that thematic argument was that people can have the power to influence the decisions that affect their lives directly.

There is a kind of mistrust in the world, in Hungary as well, even local governments are moving away from people and the needs of everyday life. For successful Participatory Budgeting, a process can make people aware of their ability to influence decisions in some way. (Interview 21)

People should feel that the decision is not being made over their heads, not with politicians, but with citizens. (Interview 10)

I see this very positively, and not because we give money to someone, but because people really have a say in what changes they make from the tax they pay, where they live, that's really fundamental. (Interview 6)

Similar to earlier findings on politicians' support for participation, an important argument from politicians was based on the educative function of participatory 


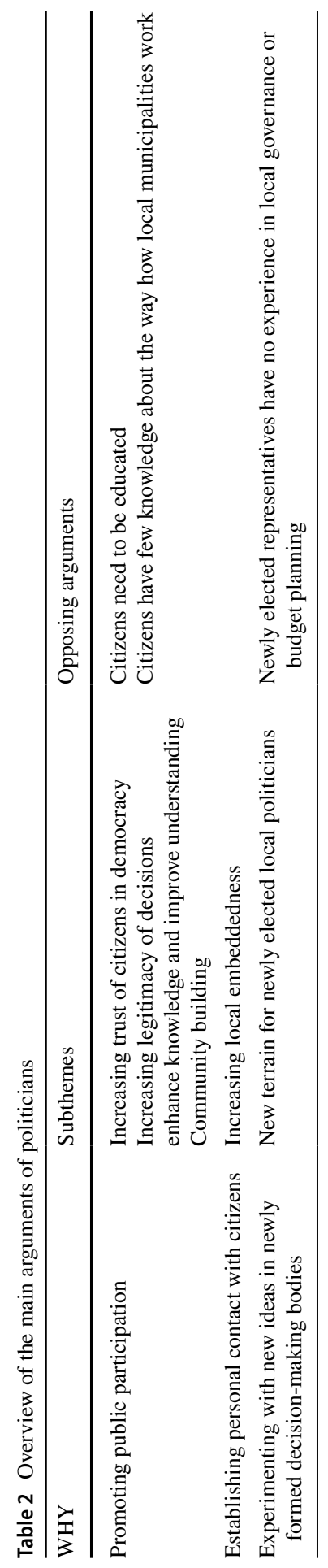


processes. Through participation people can learn democracy, learn from each other and about decision-making processes. Therefore, PB improves knowledge about the topic and improves commitment to local issues. Within that theme, community building and collective consciousness were also highlighted.

It strengthens the collective democratic consciousness and collective participation. All this is good because it educates society, citizens see its advantages and disadvantages. (Interview 15)

One of our invited politicians indicated support for public participation as a means to improve the legitimacy of decisions. If citizens are involved in the process of PB they feel the decision is their own and it makes them committed to the outcome as well.

The involvement of local residents increases the support of policies because people living there feel that the decisions are theirs. (Interview 9)

To understand the whole picture, it is also worth considering the arguments to the contrary. Representatives of the established parties also contradict some of the statements in support of promoting PB in theory, while on the other hand claim to have a positive view of participatory decision-making. The main message is that citizens are not able to understand the logic of budgetary decisions. Their knowledge is not valid for these kinds of decision-making:

The point is that people cannot comprehend everything. It can be said that the budget of the municipality is like your own household, but a multitude of people cannot control their own household budget either. There are elected leaders because, at the end of the day, decisions have to be made. (Interview 15)

But I'm skeptical about that. I think the budget is so complicated that an average citizen doesn't understand it. He doesn't understand because he doesn't even know how much a municipality does. The context of this is not seen by a citizen. (Interview 5)

Given these examples, we have to acknowledge the difference between the expressed values and the followed values. While the interviewees argued for PB in theory, when talking about citizens in practice, these politicians were not committed to real empowerment by questioning the capabilities and knowledge of citizens. In this, we can observe that theoretical arguments resonate among politicians who promote public participation, but on the other hand, the image of citizens and the relationship with citizens do not underpin their theoretical reasoning. This contradiction raises the need for further research on this topic.

\section{Establishing personal contact with citizens}

Personal meetings could be part of participatory processes-especially in PB processes. In that case, deliberation could be an important element of PB as well, and deliberative platforms such as forums can build a bridge between citizens and decision-makers. Concerning participatory democracy, there is a need for these platforms 
to connect citizens with decision-makers. These platforms can channel the needs of the public sphere to the political sphere and link them with each other through discourse or just by submitting written ideas. These thoughts appear in the interpretations of the interviewees. Some of them emphasize the need for different kinds of connections with their voters. They see PB as an opportunity to build relationships through discourse, forums and debates. "I think that this tool can greatly increase the support of the mayor and the representative body can increase social embeddedness.” (Interview 3 ).

Mainly in new parties, there is a need for new platforms to meet citizens and make connections with voters. Participatory tools such as PB can offer such a platform. "So it is helpful to see if new platforms also emerge when communicating with voters." (Interview 8).

In line with that argument, forums are the main elements of the process. It is articulated that these 'forums' or 'platforms' can be built by the process of PB and the deliberative notion of these processes was emphasized here. "You definitely need forums where you need to meet. (...) Subjective conversations are not without passion, but it can lead to connections." (Interview 21).

The argument for why PB is needed was the establishment of connections and increasing local embeddedness. This argument included that officials wanted to know more about the territory and their represented area. Specifically, they want to "know what the problem is with that district." (Interview 18) Suggesting that when they have a greater understanding of the problems in a district, "they can be fixed very quickly and in a very correct way." (Interview 18).

On the other hand, not all of the politicians are in favor of this kind of connection. Talking about the attitudes of local MPs of established parties, our interviewee explained that most of the politicians did not show up in the process, and they did not take the opportunity to deepen their relationship with their constituents. Although the original idea of PB was built on deliberative forums where citizens could present their ideas and discuss them with the local representatives, most of those representatives did not show up. The interviewee added that personal meetings were not successfully organized.

I was hoping that MPs are involved in this. Now compared to that, this personal part, it didn't go well. Because of different reasons. (Interview 10)

Concluding this argument, newly elected parties need new forms of connections to citizens. They need stronger embeddedness in their local area of representation therefore emphasize the benefits of a participatory budget in this direction. These newly elected representatives are looking for new platforms. On the other hand, the old parties do not use these arguments and platforms either. It raises the question of whether these platforms could be institutionalized in a deliberative form in the long run.

\section{New experiment}

Many politicians explained that there is a need for innovation, especially in new local municipalities. According to the interviewees', voters have high expectations from new parties. 
So here now there is a new leadership in municipalities, this is now a new opportunity. (Interview 14)

And as a result, you can start experimenting with this. I think where we are in this is a good level. (Interview 1)

One of the invited politicians added that if participatory institutions are established, and mayors and local governments start to innovate in these kinds of decision-making processes, it can be a good starting point, and citizens may get used to it. These participatory tools, especially PB, are only the first steps, but it is the beginning of an expansion of the participatory processes. As part of that explanation, politician claimed that citizens get used to participating in decisions and want more participation after the initial experiences of these processes. If these processes are successful, there will be a demand for broader applications. According to one interviewee, these institutions are in the test phase in Budapest-decision-makers would be careful with innovations and improve these institutions step by step.

When you open a door, people come in through it, and they don't want to go out anymore. That is why it can only always be expanded, which is why I think we need to proceed in stages, with careful steps. If we could do it in the capital, we could probably do it nationally. (Interview 22)

Other politicians are more skeptical about these experiments. One interviewee from an established party articulated that participatory decision-making processes are only local initiatives. They are only experiments at the local level and personal initiatives of a given mayor or other decision-makers. In that opinion, these processes were based on the engagement of the local politicians and the interviewee questioned the applicability at national level.

I think this is also in an experimental phase, but I see the reality of that (...) Clearly, individual experiments, whether this can become common, obviously depend on the personality of the given politician. (Interview 15)

A newly elected local representative was much more cautious about innovation as well. Although he was admittedly not informed on the topic of PB, he raised a relevant question that may arise in the case of today's newly elected local governments in Hungary, namely that most of the newly elected representatives have not seen a local budget before and budget planning is a novelty in itself for them.

I haven't seen real Participatory Budgeting in the country, I don't think we're there yet. Since this is the first budget, many for the first time MPs, we should not experiment with this now. (Interview 4)

Inexperience and lack of knowledge can have negative effects. The emptying of processes and the inappropriate use of concepts in this context can have a negative effect both on the decision-makers and on the citizens. The settlement of ostensible participation or 'tokenism' (Arnstein 1969), in the long run, could result in a loss of public confidence, with which politicians could achieve the exact opposite result than expected with PB. 


\section{Discussion}

Beyond presenting the three main arguments, it is important to reflect on arguments that are often discussed in the literature, for example, the 'Porto Alegre Effect' (Sintomer et al. 2016, p. 163), the role of the Brazilian experience and the alterglobalization movement on European participatory budgeting processes. It was specific to two interviewees, mainly the representatives of new parties who brought in three further arguments: social justice, green ambitions and transparency.

Similar to the European panorama of participatory processes, the issue of social justice and the impact of PB on social questions were rarely mentioned. The argument on improving social justice was brought up only by an elected representative of the Momentum Party in public office (Interview 9) and an elected representative of the Green Party in the central office (Interview 27). Therefore, it was not an emphasized element of reasons behind introducing participatory budgeting in Budapest. It was one of the leaders of the Green Party (Interview 27) who emphasized the emergence of minorities' interests vis-à-vis the majority. For example, on the issues of homelessness and future generations whose interests are not adequately represented in decision-making. Although these issues are addressed in the literature on participatory decision-making and participatory democracy (Eckersley 1999; Brulle 2002; Arias-Maldonado 2007), they were not emphasized by our interviewees.

The discourse on environmental issues was mentioned by only one elected representative in the Green Party in the central office (Interview 2). He added that "such green topics" are raised by both civil initiatives and in participatory budgeting as well. He argued that participatory budgeting could be a forum for these topics. He also mentioned the role of the future generation in such discussions. He emphasized the discourse between generations in different topics that is affecting the future of the youngsters and participatory budgeting could give space to these discussions. Although environmental democracy is a relevant topic related to participatory decision-making (Eckersley 1999; Brulle 2002; Arias-Maldonado 2007), most of the politicians did not highlight this point in our interviews.

Interestingly, the topic of transparency was mentioned by only one interviewee.

It is extremely important that in modern terms, the implementation is transparent. (...) This is extremely important and is part of the methodology of the Participatory Budgeting. (Interview 11)

The level of transparency of local budgets is especially low in Hungarian local governments, which has been raised by NGOs in recent years (Merényi 2020). Although PB can be a tool to improve the transparency of planning and financial issues at the local level, this argument is rare even among the newly elected representatives. Although PB can be an appropriate tool for raising public awareness of public finances, politicians in our research did not mention these arguments.

Regarding the limitations of our research, the selection of our interviewees is biased toward politicians who had some experience and knowledge on the topic. We have good reasons to believe that another sampling strategy focused on a more 
diverse set of politicians would have brought more negative arguments than from those who have little knowledge about participation and even the essence of PB; however, generalization was not our aim in this research. Instead, we wanted to explore the argumentation of affected politicians and understand the reasons behind why politicians decide to apply Participatory Budgeting.

\section{Conclusion}

In this article, we explored the main arguments politicians use to answer why Participatory Budgeting was implemented in Budapest. The three main arguments that we found were: (1) promoting public participation; (2) PB is an effective communication tool that connects politicians with citizens; and (3) PB is a new experiment. In addition to the theoretical argument of promoting public participation of the scholarly sources on civic participation that turned out to be well known among politicians, we identified the possibility of contact with the electorate and the intention of the newly elected representatives to experiment with democratic innovations. Previous research resonates with the main findings to the extent that political leaders prefer informal channels to formal participatory instruments and the main reasons of political leaders to support public participation are related to collecting information and connecting with real people (Hendriks and Lees-Marshment 2019). The contradiction that politicians emphasize theoretical arguments, but yet view citizens as incapable of reaching logical budget decisions, raises the need for further research on this topic-especially in the Central and Eastern European context.

The new findings of this research can add to the explanation of the Participatory Budgeting as an innovation or new experiment. We concluded that one of the most emphasized arguments for why politicians decided to use participatory budgeting is the intention innovate by using democratic platforms to contact citizens. This also anticipates the dangers that need to be considered. Implementation of new participatory tools in practice of local governments means the introduction of new concepts and terms. If the institutionalization of these processes is failed, these terms can be misunderstood and inexperience can lead to failure as we could see in other cases (Boc 2019; Schiffbeck 2018). In general, the risks of institutionalization of new institutions such as Participatory Budgeting can be reduced if various actors that have contributed to the spread of Participatory Budgeting in Europe (Sintomer et al. 2016) are involved in the innovation and stabilization of these new tools of decision-making. Additionally, future research can reveal if this argument of politicians is related to the acceptance of co-production (Escobar 2020), the process through which participatory budgeting can involve knowledge of citizens, civil society organizations, and international organizations to improve the level of public policies in a longer run.

\section{Appendix 1}

See Table 3. 


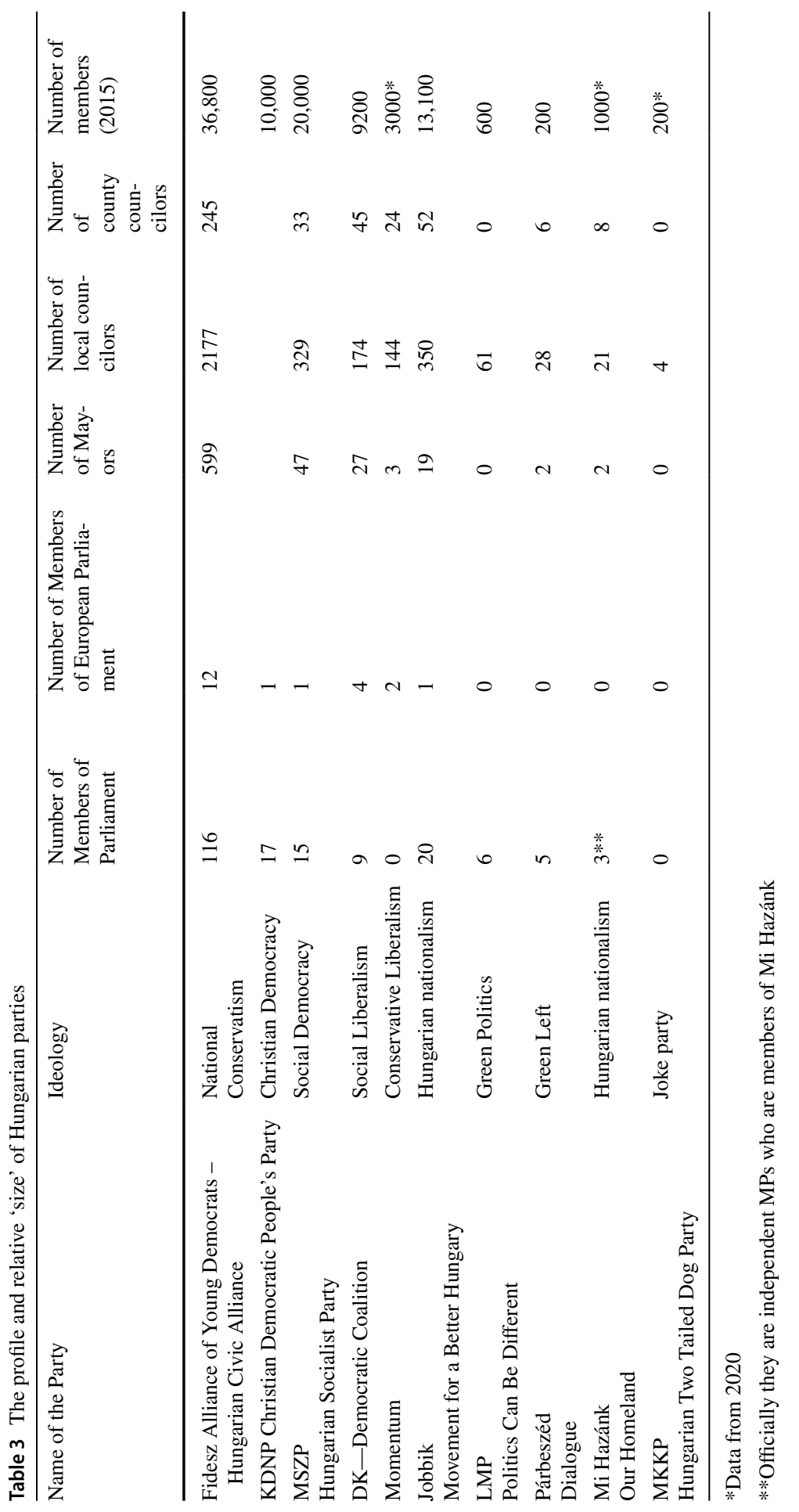




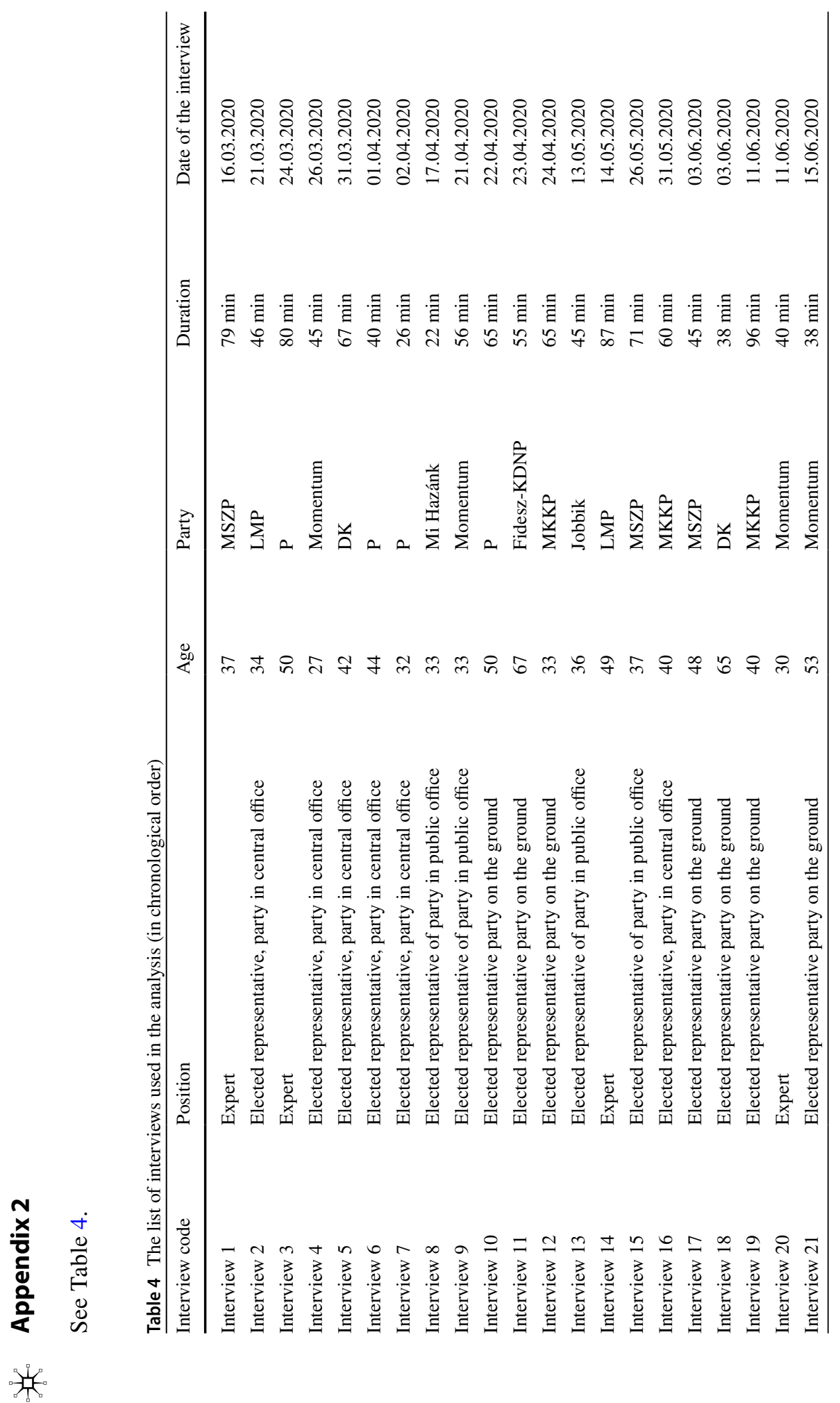




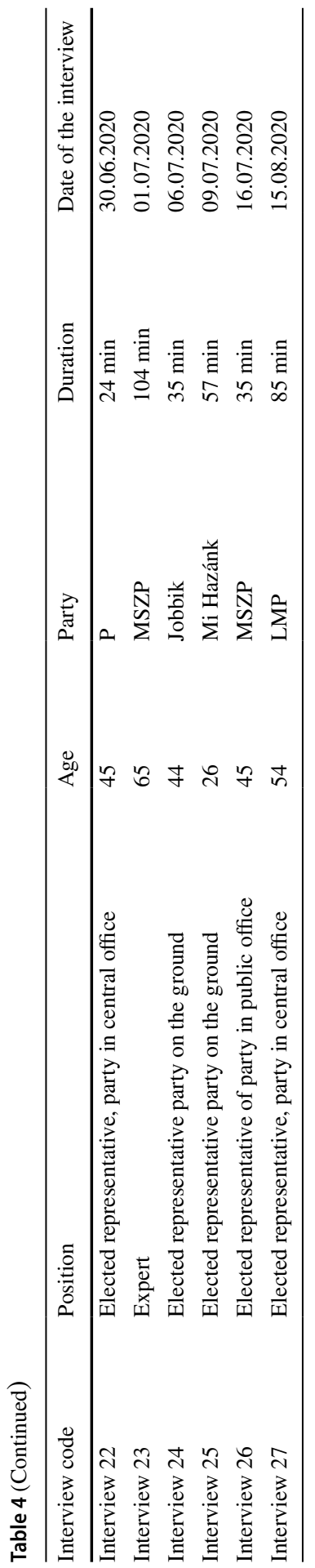


Funding Open access funding provided by Centre for Social Sciences. This work was supported by Hungarian Research Fund (PD_131408) and by Cost Action "Constitution making and deliberative democracy” (CA17135), supported by COST (European Cooperation in Science and Technology).

\section{Declarations}

Conflict of interest On behalf of all authors, the corresponding author states that there is no conflict of interest.

Open Access This article is licensed under a Creative Commons Attribution 4.0 International License, which permits use, sharing, adaptation, distribution and reproduction in any medium or format, as long as you give appropriate credit to the original author(s) and the source, provide a link to the Creative Commons licence, and indicate if changes were made. The images or other third party material in this article are included in the article's Creative Commons licence, unless indicated otherwise in a credit line to the material. If material is not included in the article's Creative Commons licence and your intended use is not permitted by statutory regulation or exceeds the permitted use, you will need to obtain permission directly from the copyright holder. To view a copy of this licence, visit http://creativecommons.org/licen ses/by/4.0/.

\section{References}

Abers, R. 2000. Inventing local democracy. Grassroots politics in Brazil. Boulder: Lynne Rienner.

Ariely, D. 2010. Upside of irrationality: The unexpected benefits of defying logic at work and at home. New York: HarperCollins.

Arnstein, Sherry R. 1969. A ladder of citizen participation. Journal of the American Planning Association 35 (4): 216-224.

Arias-Maldonado, M. 2007. An imaginary solution? The green defence of deliberative democracy. Environmental Values 16 (2): 233-252. https://doi.org/10.3197/096327107780474573.

Bächtiger, A., J.S. Dryzek, J. Mansbridge, et al. 2018. The Oxford handbook of deliberative democracy. Oxford: Oxford University Press.

Barber, B.R. 1984. Strong democracy: Participatory politics for a new age. Berkeley: University of California Press.

Boc, E. 2019. The development of participatory budgeting processes in Cluj-Napoca. Transylvanian Review of Administrative Sciences 58: 38-51.

Bozóki, A., and D. Hegedûs. 2018. An externally constrained hybrid regime: Hungary in the European Union. Democratization 25 (7): 1173-1189.

Braun, Virginia, and Victoria Clarke. 2006. Using thematic analysis in psychology. Qualitative Research in Psychology 3 (2): 77-101. https://doi.org/10.1191/1478088706qp063oa.

Brulle, R.J. 2002. Habermas and green political thought: Two roads converging. Environmental Politics 11 (4): 1-20. https://doi.org/10.1080/714000651.

Buzogány, Á. 2017. Illiberal democracy in Hungary: Authoritarian diffusion or domestic causation? Democratization. https://doi.org/10.1080/13510347.2017.1328676.

Caluwaerts, D., and M. Reuchamps. 2015. Strengthening democracy through bottom up deliberation: an assessment of the internal legitimacy of the G1000 project. Acta Politica 50 (2): 151-170. https://doi.org/10.1057/ap.2014.2.

Caluwaerts, D., and M. Reuchamps. 2018. The legitimacy of citizen-led deliberative democracy. London: Routledge.

Dalton, R.J. 2008. Citizenship norms and the Expansion of political participation. Political Studies 56: 76-98.

Davidson, S., and A. Stark. 2011. Institutionalising public deliberation: Insights from the Scottish Parliament. British Politics 6 (2): 155-186.

Dean, R.J. 2017. Beyond radicalism and resignation: The competing logics of public participation in policy decisions. Policy \& Politics 45 (2): 213-230. 
Dean, R. 2019. Control or influence? Conflict or solidarity? Understanding diversity in preferences for public participation in social policy decision making. Social Policy \& Administration 53 (1): $170-187$.

Dias, N. 2020. Hope for democracy. In Hope for Democracy: Oxford University Press. https://doi.org/10. 1093/oso/9780190084523.001.0001.

Dryzek, J. S., A. Bächtiger, S. Chambers, et al. 2019. The crisis of democracy and the science of deliberation. Science 363 (6432): 1144-1146.

Eckersley, R. 1999. The discourse ethic and the problem of representing nature. Environmental Politics 8 (2): 24-49. https://doi.org/10.1080/09644019908414460.

Elstub, S., and O. Escobar. 2019. Handbook of democratic innovation and governance. Cheltenham: Edward Elgar.

Escobar, O. 2020. Transforming lives, communities and systems? Co-production through participatory budgeting. In Handbook of co-production of public services and outcomes, ed. E. Loeffler and T. Bovaird. NewYork: Palgrave Macmillan.

Fishkin, J., R.C. Luskin, J. Panaretos, A. Siu, and E. Xekalaki. 2008. Returning deliberative democracy to Athens: Deliberative polling for candidate selection. SSRN 1142842.

Fishkin, J.S., and R.C. Luskin. 2005. Experimenting with a democratic ideal: Deliberative polling and public opinion. Acta Politica 40 (3): 284-298. https://doi.org/10.1057/palgrave.ap.5500121.

Flinders, M., and D. Curry. 2008. Deliberative democracy, elite politics and electoral reform. Policy Studies 29 (4): 371-392.

Fung, A. 2007. Minipublics: Deliberative designs and their consequences. In Deliberation, participation and democracy: Can the people govern?, ed. S.W. Rosenberg, 159-183. Basingstoke: Palgrave Macmillan.

Geissel, B., and K. Newton, eds. 2012. Evaluating democratic innovations: Curring the democratic malaise? New York: Routledge.

Geissel, Brigitte, and Joas Marko. 2013. Participatory democratic innovations in Europe. Improving the quality of democracy? Opladen: Barbara Budrich.

Gherghina, S. 2014. Party organization and electoral volatility in Central and Eastern Europe: Enhancing voter loyalty. Abingdon: Routledge.

Gherghina, S., J. Ekman, and O. Podolian. 2018. Democratic innovations in Central and Eastern Europe: Expanding the research agenda. Contemporary Politics 25 (1): 1-10.

Gherghina, S., and V. Jacquet. 2019. Political parties and deliberation: An analytical framework. Paper prepared for the 47th ECPR Joint Sessions, UCLouvain, Mons, Belgium 8-12 April 2019. https:// ecpr.eu/Filestore/PaperProposal/fcf7055f-ce48-4945-8044-bbbd77696cd2.pdf.

Gherghina, S., S. Soare, and V. Jacquet. 2020. Deliberative democracy and political parties: functions and consequences. European Political Science. https://doi.org/10.1057/s41304-019-00234-0.

Goodin, R. 2008. Innovating democracy: Democratic theory and practice after the deliberative turn. Oxford: Oxford University Press.

Gourgues, Guillaume. 2013. Les politiques de démocratie participative. Grenoble: Presses universitaires de Grenoble.

Grönlund, K., A. Bächtiger, and M. Setälä, eds. 2014. Deliberative mini-publics. Involving citizens in the democratic process. Colchester: ECPR Press.

Hendriks, C.M., and J. Lees-Marshment. 2019. Political leaders and public engagement: The hidden world of informal elite-citizen interaction. Political Studies 67 (3): 597-617.

Hernández-Medina, Esther. 2010. Social inclusion through participation: The case of the participatory budget in São Paulo: Social iclusion through participation in São Paulo. International Journal of Urban and Regional Research 34 (3): 512-532. https://doi.org/10.1111/j.1468-2427.2010.00966.x.

Habermas, J. 1996. Between facts and norms: Contributions to a discourse theory of law and democracy, 631. New York: MIT.

Hickman, P. 2006. Approaches to tenant participation in the English local authority sector. Housing Studies 21 (2): 209-225.

Herzog, Olga. 2016. 'Representatives' support for direct democracy: Intrinsic policy-seeking or just a new instrument of power-seeking?' Presented in the ECPR General Conference, Prague.

Iyengar, S. 2010. The art of choosing. London: Hachette.

Invernizzi-Accetti, C., and F. Wolkenstein. 2017. The crisis of party democracy, cognitive mobilization, and the case for making parties more deliberative. American Political Science Review 111 (1): 97-109. https://doi.org/10.1017/S0003055416000526. 
Johnson, J. 2006. Political parties and deliberative democracy. In Handbook of party politics, 47-50. Thousand Oaks: Sage.

Jacquet, V., C. Niessen, and M. Reuchamps. 2020. Sortition, its advocates and its critics: An empirical analysis of citizens' and MPs' support for random selection as a democratic reform proposal. International Political Science Review. https://doi.org/10.1177/0192512120949958.

Jacquet, V., N. Schiffino, M. Reuchamps, and Delphine Latinis. 2015. Union sacrée ou union forcée ? Les parlementaires belges face à l'impératif délibératif. Participations 3 (13): 171-203.

K-Monitor, 2019. Helyi együttmúködések rendszere - Ötletek az önkormányzatiság megújításához. Retrieved October 14, 202 from https://k.blog.hu/2019/11/19/atlathato_reszveteli_onkormanyz atisag.

Katz, Richard S., and Peter Mair. 1993. The evolution of party organizations in Europe: The three faces of party organization. American Review of Politics 14: 593-617.

Kempa, Jarosław, and Artur Roland Kozłowski. 2020. Participatory budget as a tool supporting the development of Civil Society in Poland. Nispacee Journal of Public Administration and Policy 13: 61-79. https://doi.org/10.2478/nispa-2020-0003.

King, C.S., M.F. Kathryn, and B.O. Susel. 1998. The question of participation: Toward authentic public participation in public administration. Public Administration Review 58 (4): 317-326.

Király, G., A. Köves, G. Pataki, and G. Kiss. 2016. Assessing the participatory potential of systems mapping. Systems Research 33: 496-514. https://doi.org/10.1002/sres.2374.

Kiss, G. 2014. Why should the public participate in environmental decision-making? Theoretical arguments for public participation. Periodica Polytechnica Social and Management Sciences 22 (1): 13-20. https://doi.org/10.3311/PPso.7400.

Kovarek, Dániel., and Gábor. Soós. 2017. Hungary: Cut from the same cloth? A comparative analysis of party organizations in Hungary. In Organizational structures of political parties in Central and Eastern European Countries, ed. Katarzyna Sobolewska-Myślik, Beata Kosowska-Gąstoł, and Piotr Borowiec, 185-208. Press: Jagiellonian University.

Laird, F.N. 1993. Participatory analysis, democracy, and technological decision making. Science, Technology and Human Values 18 (3): 341-361.

Macq, Hadrien, and Vincent Jacquet. 2020. The Politics of Citizens' Assemblies: Why political leaders establish participatory and deliberative institutions. Paper presented at the workshop 'One year of Permanent Citizens' Dialogue in the Germanspeaking Community of Belgium,' 21 September 2020.

Markowski, R. 2001. Democratic consolidation and accountability: News from Eastern and Central European democracies. In Transformative Paths in Central and Eastern Europe, ed. E. Wnuk-Lipinski and R. Markowski, 47-72. Instytut Studiów Politycznych Polskiej Adamemii Nauk: Warsaw.

Mckenna, D. 2012. Local politicians' attitudes towards participatory initiatives: A Bulpittian perspective. Public Money \& Management 32 (2): 103-110. https://doi.org/10.1080/09540962.2012.656012.

Merényi, M. 2020. A részvételi költségvetés esélyei a magyar önkormányzatokban. K-Monitor, 2020. https://www.fes-budapest.org/fileadmin/user_upload/dokumente/pdf-dateien/A_reszveteli_kolts egvetes_eselyei_20200210.pdf.

Nez, H. 2016. Does participation mean reciprocal learning? The relationships between diverse stakeholders during participatory budgeting in Paris. Journal of Civil Society 12 (3): 266-281. https://doi.org/ 10.1080/17448689.2016.1215371.

O'Leary, Z. 2014. The essential guide to doing your research project, 2nd ed. Thousand Oaks, CA: SAGE.

Oross, D., and K. Pócza. 2019. Constitutional Changes in Hungary and the National Consultation as a Deliberative Practice. Paper presented at the Political Parties and Deliberative Practices: Use and Abuse workshop, ECPR 2019 Joint Sessions of Workshops, Mons, Belgium, 8-12 April. https:// ecpr.eu/Events/PaperDetails.aspx?PaperID=44382\&EventID=121.

Pállinger, Z. 2016. The Uses of Direct Democracy in Hungary Paper presented at the ECPR 2016 Generals Conference Section 16, Panel P097: Direct Democracy and Online Political Participation.

Patsias, C., A. Latendresse, and L. Bherer. 2012. Participatory democracy, decentralization and local governance: The Montreal participatory budget in the light of 'empowered participatory governance' $z$ the Montreal participatory budget”. International Journal of Urban and Regional Research 37 (6): 2214-2230. https://doi.org/10.1111/j.1468-2427.2012.01171.x.

Pilet, J.-B., and W.P. Cross (Eds.) The selection of political party leaders in contemporary parliamentary democracies: A comparative study (pp. 156-171). London: Routledge.

Sintomer, Y., A. Röcke, and C. Herzberg. 2016. Participatory budgeting in Europe: Democracy and public governance. London: Routledge. 
Smith, G. 2009. Democratic Innovations. Designing institutions for citizen participation. Cambridge: Cambridge University Press.

Schiffbeck, A. 2018. Attrition in long-term deliberative processes. The neighbourhood consultative councils in Timisoara. Contemporary Politics 25 (1): 94-110.

Schiffino, N., V. Jacquet, M. Cogels, et al. 2019. Les gouvernants face aux transformations de la démocratie. Le point de vue des ministres et des présidents de parti. Gouvernement Et Action Publique 2 (2): $57-80$.

Seawright, J., and J. Gerring. 2008. Case Selection techniques in case study research: A menu of qualitative and quantitative options. Political Research Quarterly 2008 (61): 294. https://doi.org/10.1177/ 1065912907313077.

Sipos-Reszkető. 2019. Budapest Participatory Budget, case study report https://www.participativni-rozpo cet.cz/wp-content/uploads/2019/03/REPORT_BUDAPEST-PB.pdf.

Talpin, J. 2011. Schools of democracy. How ordinary citizens (sometimes) become competent in participatory budgeting institutions. Colchester: ECPR Press.

Wilcox, D. 1994. Guide to effective participation. Joseph Rowntree Foundation.

Wampler, B. 2012. Participation, representation, and social justice: Using participatory governance to transform representative democracy. Polity, Deepening Democracy 44 (4): 666-682.

\section{Manifestos}

Budapest 2.0. https://budapest.momentum.hu/wp-content/uploads/2019/05/budapest_2.0_final-Lite.pdf.

Budapest Mindenkié! Karácsony Gergely Főpolgármester-jelölt programja. https://parbeszedmagyarorsza gert.hu/files/public/budapest_mindenkie_1.pdf.

Gajda Péter Polgármesteri program 2019. https://www.gajdapeter.hu/Polgarmesteri_program_2019.pdf.

Polgármesteri program 2014. https://www.gajdapeter.hu/polgarmesteri_program_2014.pdf.

Publisher's Note Springer Nature remains neutral with regard to jurisdictional claims in published maps and institutional affiliations. 